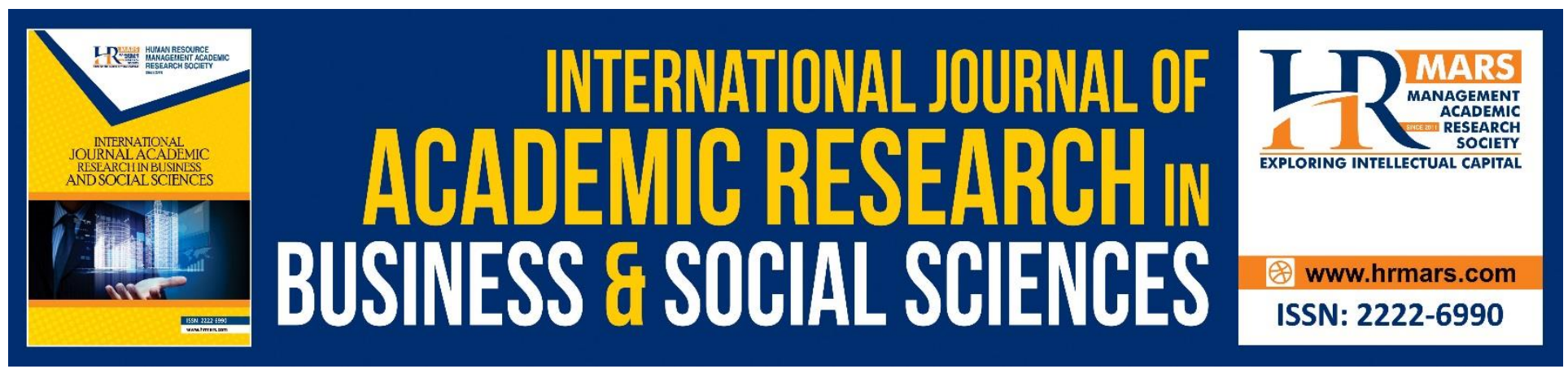

\title{
Determinants of Takaful: Case in East Coast Region of Malaysia
}

Hartini Ab Ghani \& Salman Lambak

To Link this Article: http://dx.doi.org/10.6007/IJARBSS/v8-i12/5059

DOI: $10.6007 /$ IJARBSS/v8-i12/5059

Received: 21 Oct 2018, Revised: 30 Nov 2018, Accepted: 19 Dec 2018

Published Online: 29 Dec 2018

In-Text Citation: (Ghani \& Lambak, 2018)

To Cite this Article: Ghani, H. A., \& Lambak, S. (2018). Determinants of Takaful: Case in East Coast Region of Malaysia. International Journal of Academic Research in Business and Social Sciences, 8(12), 622-628.

Copyright: (C) 2018 The Author(s)

Published by Human Resource Management Academic Research Society (www.hrmars.com)

This article is published under the Creative Commons Attribution (CC BY 4.0) license. Anyone may reproduce, distribute, translate and create derivative works of this article (for both commercial and non-commercial purposes), subject to full attribution to the original publication and authors. The full terms of this license may be seen at: http://creativecommons.org/licences/by/4.0/legalcode

Vol. 8, No. 12, 2018, Pg. 622 - 628

http://hrmars.com/index.php/pages/detail/IJARBSS

JOURNAL HOMEPAGE

Full Terms \& Conditions of access and use can be found at http://hrmars.com/index.php/pages/detail/publication-ethics 


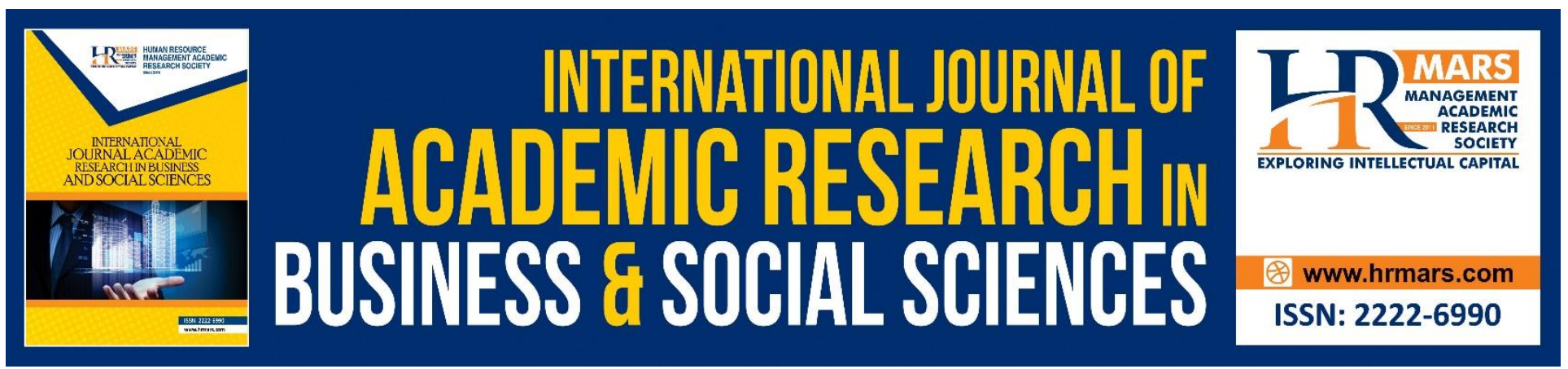

\title{
Determinants of Takaful: Case in East Coast Region of Malaysia
}

\author{
Hartini Ab Ghani \\ Faculty of Economics and Management Sciences, Universiti Sultan Zainal Abidin, Kuala Terenganu, \\ Terengganu, Malaysia \\ Email: hartinighani@unisza.edu.my \\ Salman Lambak \\ Faculty of Economics and Management Sciences, Universiti Sultan Zainal Abidin, Kuala Terenganu, \\ Terengganu, Malaysia \\ Email: salmanlambak@unisza.edu.my
}

\begin{abstract}
Takaful (Islamic insurance) industry is a developing rapidly in Malayssia since it was launched in the early 1984. It has emerged as an important component of the Islamic financial system in the country on competitive basis with conventional insurance. A clear understanding of consumer requirements is an essential to assist the provider of takaful in Malaysia to be proactive in offering an Islamic financial service with reliable information. This study is to determine the factors that influence the participation in Takaful (Islamic insurance) among the consumers in the East Coast regison of Malaysia. 100 respondents were selected in this study through the questionnaire. The data was analysed using Statistical Package for Social Sciences (SPSS) version 20.0. Descriptive analysis and correlation were applied to this study.
\end{abstract}

Keywords: Takaful, Religiosity, Attitude, Family Takaful.

\section{Introduction}

Today, the Muslim consumers have become more conscious and sensitive towards Halal(lawful) requirements. Muslim consumers are looking for specific products tailored to meet their religious and community needs. They have begun questioning and avoiding goods which were not certified as which do not have the Halal sign (Sadek, 2001). The halal conscious does not stop at good consumption but also when it comes to purchasing of insurance products. Insurance is an important mechanism whereby individual or business transfer some of their uncertainty of risk to insurer. Insurance is considered as one of the oldest and well known financial products but there are still many who shy away from it and would not purchase it at free will. Insurance is quite a complex 
product and in the Asian society, some find it a taboo to talk about unfortunate circumstances such as death, disability or ill health. However, given life uncertainties, insurance helps to cushion and minimize the loss that consumers and households incur in the event of unfortunate incidents (Loke \& Goh, 2012).

However, due to the existence of Islamically unacceptable elements in its operation such as riba, gharar and maysir, conventional insurance is considered haram (unlawful) to the Muslims community. Hence, Takaful has become the alternative method of providing insurance services that is deemed acceptable for Muslims as it is free from the element of riba, maysir and gharar. Takaful is based on the principle of Tabarru' (donation/charity) and the distribution is based on ta'wun (solidarity and mutual assistance). It is important to understand the factors that influence the consumers' participation intention as it lead to an increase in penetration rate of Takaful contribute significantly in stimulating the economic growth through its role as risk transfer mechanism and financial intermediation. It is also agreed by Liaw (2008), as consumers' purchase intention increased, they will likely to share their experiences with people nearby, which known as word-of-mouth, and will give others their suggestions as well as recommendations. Thus, it will be able to influence other potential consumers to participate in Takaful scheme. Therefore, by understanding consumers' purchase intention, insurance providers or Takaful operators will be able to meet the policyholders needs and wants which will lead to satisfaction among policyholders. Hence, this paper sets out to identify the factors that drive the demand for life insurance in Malaysia. The findings of this paper will help to accelerate the growth of the Takaful market in Malaysia. A vibrant Family Takaful market helps to create sustainable economic and financial development. In this study, the researcher will focus in deep into attitude snd religiosity and the way it influences participation intention among Muslim consumers in the East Coast Region of Malaysia towards Family Takaful.

\section{Literature Review}

The beginning of insurance in Malaysia can be traced to the colonial period between the eighteenth and nineteenth centuries, The development of the industry in the 1980s was aspired by the prevailing need of the Malaysian Muslim public for the benefits of protection as provided by the insurance but on a basis that is approved by the Shariah principles. the Takaful system is based on mutual cooperation, responsibility, assurance, protection and assistance between groups of participants, which represents a form of mutual insurance. Under the Takaful scheme, Takaful participants (also known as policyholders in insurance) agree to mutually guarantee each other against a defined loss or damage that may happen to any of them by contributing as Tabarru' (donation) in the Takaful funds. It emphasises unity and co-operation among participants. The essence of the Takaful scheme that makes it acceptable in Islam is the element of the embedded Tabarru' contract, which is the agreement by a participant to relinquish as a donation a certain proportion of the Takaful contribution (also known as premium in insurance) that he agrees or undertakes to pay. Through this donation, he will be able to fulfil his obligation of mutual help and joint guarantee should any of his fellow participants suffer a defined loss.

Past studies in life insurance included in the demand for life insurance are income, education, occupation, age of the head of household, number of dependents, ethnicity and risk aversion. expected inflation rate, average life expectancy, policy loading charge and social security benefits. 
The intention of participating in Takaful scheme preceded the process before actual participation into the Takaful scheme. Intention reflects future behavior. Attitude is postulated to have a direct relationship with intention behavior. Attitude is the evaluation of performing a particular behavior involving the attitude object, such as buying the product Blackwell et al., 2006).

Consumers with high positive attitudes appeared to have greater intentions to intent to participate in Takaful scheme. Ajzen (1988) stated that attitude can be described as an important element in predicting and describing human behavior. Consumers are influenced by different factors when trying to decide on whether or not to acquire a new product (Rehman \& Shabbir, 2010). Generally, consumer's intention and behaviour are influenced by their religion (Delener, 1994).

\section{Methodology}

A total of 100 questionnaires have been distributed and 100 set of questionnaires or $100 \%$ were returned by the respondents who are the conventional life insurance policyholders in the East Coast region of Malaysia (Kota Bharu, Kuantan and Kuala Terengganu) using purposive sampling. The purposive sampling is a form of non-probability sampling in which decisions concerning the participants to be the sample are taken by the researcher as the researcher are seeking for one predefined group, the conventional life insurance policyholders and willing to participate in survey. Data were obtained using a structured questionnaire through a survey. There are three sections in the questionnaire;(1) demographic background, (2) attitude, (3) religiosity and (4) intention to participate. The Attitude section consists of the six items and the intention section consists of the seven items. Respondent were asked to use a 5 point Likert-type scale ranges from 1 (strongly disagree) to 5 (strongly agree). Analysis of data was done using statistical analysis from the SPSS version 21. Descriptive methods were used to simplify and characterise the data. Further analysis included descriptive statistic and correlation testing.

\section{FINDINGS}

\section{Profile of Respondents}

The analysis was performed on gender, age, education level, occupation, household income, number of years purchase conventional life insurance policy, current type of conventional life insurance policy and few questions relating to participating in Takaful scheme. The result of gender of respondents shows that $63 \%$ respondents are female while $37 \%$ respondents are male. From total of respondents, $41 \%$ from them are from range $21-30$ years old. It is followed by the range of $31-40$ years old, $34 \%$. Meanwhile, $19 \%$ respondents are from $41-50$ years old and the remainder $6 \%$ are from the age range of $51-60$ years old. The result shows that 50\% Bachelor Degree's holder, 26\% had Master/Ph.D, $14 \%$ are Diploma holder and the remaining of $10 \%$ are others (professional degree). Majority of respondents had an income below RM 3000 (45\%) whereas $36 \%$ had income RM 3000 to RM5000. $85 \%$ of the respondents heard about Takaful but only $8 \%$ had participate in Family Takaful and the $92 \%$ do not participate in Family Takaful. Meanwhile, $68 \%$ respondents that havenot participate in the Takaful scheme indicate intention to participate in the Takaful scheme, $24 \%$ do not intend to participate in the Takaful scheme and another $8 \%$ had participated in the Takaful scheme. 


\section{Descriptive Statistics}

Table 1 shows descriptive statistics for all variables. The result shows that mean for attitudes is 4.02. This variable is the highest mean while the least mean is intention to purchase with 4.58. For standard deviation, it shows that high standard deviation is intention to purchase; 0.622 while lowest standard deviation is attitudes with 0.331 .

Table 1 : Descriptive Statistics

\begin{tabular}{lccc}
\hline & $\mathrm{N}$ & Mean & Std Deviatior \\
\hline Attitudes & 100 & 4.02 & 0.681 \\
Religiosity & 100 & 4.01 & 0.732 \\
$\begin{array}{l}\text { Intention to } \\
\text { participate }\end{array}$ & 100 & 4.35 & 0.73 \\
\hline
\end{tabular}

\section{Correlation Analysis}

The result in Table 2 below shows the Correlation Analysis which is that to measure the relationship for all intentio $\mathrm{n}$ of independent variables together with dependent variables. The correlation between attitude and intention to purchase is highly significant at the level of 0.769 and it is positive correlation. As such, we can say that consumers with high positive attitudes appeared to have greater intentions to intent to participate in Takaful scheme.

The result for religiosity is also significant at the level of 0.028 and it is positve correlations between religiosity and intention to participate in Takaful scheme. However, the significance level for religiosity and intention to participate is very low. Therefore, we could conclude that religiosity is not the main determinants in intention to participate in the Takaful scheme.

Table 2 : Correlation Analysis Result

\begin{tabular}{lllc}
\hline & & Attitude & Religiosity \\
\hline \multirow{3}{*}{ Intention } & $\begin{array}{l}\text { Pearson } \\
\text { Correlation } \\
\text { Sig. (2- } \\
\text { tailed) }\end{array}$ & $0.769^{* *}$ & $0.028^{* *}$ \\
\hline
\end{tabular}




\section{Discussion and Conclusion}

In light of the low penetration rate and untapped market for Takaful in Malaysia, this paper sets out to investigate the socio-economic factors that determine the demand for Family Takaful specificallyt in East Coast Region of Malaysia. It is found that age, gender, income, education, and occupation are significant determinants for the demand of Family Takaful in the East Coast Region of Malaysia. Firstly, the findings indicate that Family Takaful appear to be more popular among the respondents who are in the 20s to 30s as they are those who do not have conventional life insurance yet. Secondly, the result shows that there is a positive relationship between attitude and Intention to participate in Takaful scheme. Attitude is an important factor in influencing consumer intention in participating in Family Takafu because those with high positive attitudes appeared to have greater intentions to intent to participate in Family Takaful. This paper draws out two important findings in the demand for life insurance in Malaysia.. One of the limitations is this study only covered East Coast Region of Malaysia. It still did not cover the total population of Malaysia. Thus, it is suggested that the future research can be done for the whole Malaysia so the result we get will be more comparable and provide workable direction in Family Takaful. Higher number of responses will allow for more robust statistical analyses such as Structural Equation Modeling. Despite its limited sample, the findings from this study can be used to better understand the participation behavior related to Family Takaful.

\section{References}

Ajzen, I. (1988). Attitudes, Personality and Behavior (1st Editio). United Kingdom: Open Univervisity Press.

Delener, N. (1994). Religious Contrasts in Consumer Decision Behaviour Patterns : Their Dimensions. European Journal of Marketing, 28(5), 36-53.

Loke, Y., \& Goh, Y. (2012). Demand for Life Insurance in Malaysia. In International Conference on Economics and Finance Research (Vol. 43, pp. 104-108). Retrieved from http://www.ipedr.com/vol43/022-ICFME2012-X00004.pdf

Rehman, A.-, \& Shabbir, M. S. (2010). The relationship between religiosity and new product adoption. http://doi.org/10.1108/17590831011026231

Liaw, J. (2008). The challenges of Islamic branding: navigating emotions and halal. Journal of Islamic marketing, 2(1), 28-42.

Beenstock, M., Dickinson, G. and Khajuria, S. (1986) "The Determination of Life Premiums: An International Cross-Section Analysis 1970-1981," Insurance: Mathematics and Economics, vol. 5, no. 4, pp. 261-270.

Browne, M. J. and Kim, K. (1993) "An International Analysis of Life Insurance Demand," Journal of Risk and Insurance, vol. 60, no. 4, pp. 616-634.

Hammond, J. D., Houston, D. B. and Melander, E. R. (1967) "Determinants of Household Life Insurance Premium Expenditure: An Empirical Investigation," Journal of Risk and nsurance, vol. 34, no. 3, pp. 397-408.

Outreville, J. F. (1996) "Life Insurance Markets in Developing Countries," Journal of Risk and Insurance, vol. 63, no. 2, pp. 263-278. 
INTERNATIONAL JOURNAL OF ACADEMIC RESEARCH IN BUSINESS AND SOCIAL SCIENCES

Vol. 8, No. 12, Dec, 2018, E-ISSN: 2222-6990 @ 2018 HRMARS

Campbell, R. (1980) "The Demand for Life Insurance: An Application of the Economic of Uncertainty," Journal of Finance, vol. 35, no. 5, pp.1155-1172.

Rehman, A. \& Shabbir, M. S. (2010). The relationship between religiosity and new product adoption. http://doi.org/10.1108/17590831011026231

Sadek, A.H. (2001). Levetiracetam related behavioral events- a post marketing study. Presented European Congress of Epileptology 